\title{
Approximations and possibilities about Struggles content into school environment:
}

\section{an integrative review}

\author{
Aproximações e possibilidades acerca do conteúdo Lutas no ambiente escolar: uma revisão
}

integrativa

Aproximaciones y posibilidades sobre las luchas de contenido en el ámbito escolar: una revisión

integradora

Received: 12/05/2021 | Reviewed: 12/10/2021 | Accept: 12/17/2021| Published: 12/24/2021

\author{
Vinícius Dias de Carvalho \\ ORCID: https://orcid.org/0000-0002-7832-4369 \\ Federal Institute of Piauí, Brazil \\ E-mail: vinicius.dias@ifpi.edu.br \\ Paulo Adriano Schwingel \\ ORCID: https://orcid.org/0000-0002-2935-3403 \\ University of Pernambuco, Brazil \\ E-mail: paulo.schwingel@upe.br \\ Ricardo Kenji Shiosaki \\ ORCID: https://orcid.org/0000-0001-9338-5824 \\ University of Pernambuco, Brazil \\ E-mail: ricardo.shiosaki@upe.br
}

\begin{abstract}
School Physical Education works with a range of contents that aim to contemplate Movement Corporal Culture, among these are Struggles. Using literature in order to understand how research deals with this topic is essential for understanding its strengths and limitations. Following the integrative review method, this study's purpose was to identify possible contributions of Struggles over integral human formation of students, into Educational Sports context. A preliminary literature search identified 192 articles published between 2015 and 2020. Studies were evaluated within three categories: Struggles into school environment, teacher formation and Educational Sport aspects. Review resulted to 6 articles according to inclusion and exclusion criteria. Despite limitations around studies on area, results indicate Struggles content is recognized both in educational legislation and by researchers of this field; Physical education professionals have various difficulties for applying Struggles in their classes, mainly alleging problems in their teacher formation; and Educational Sports aspects appear in a non-convincing way, without empirical deepening, nor research applied to this specific theme. It is concluded that Struggles use is possible at school, but it requires confrontations, and Struggles contextualization inside Educational Sport principles is still vaguely explored, making it a field of possibilities for future researches.
\end{abstract}

Keywords: Sport; Physical education; School; Struggles.

\section{Resumo}

A Educação Física Escolar trabalha uma gama de conteúdos que visam contemplar a Cultura Corporal do Movimento, dentre esses estão as Lutas. Recorrer à literatura a fim de entender como as pesquisas tratam esse tema é fundamental para compreensão de suas potencialidades e limitações. Seguindo o método de revisão integrativa, o propósito deste estudo foi identificar as possíveis contribuições das Lutas na formação integral humana de estudantes, no contexto do Esporte Educacional. Uma pesquisa preliminar da literatura identificou 192 artigos publicados entre 2015 e 2020 . Os estudos foram avaliados dentro de três categorias: Lutas no ambiente escolar, formação docente e aspectos do Esporte Educacional. A revisão resultou em 6 artigos que atenderam aos critérios de inclusão e exclusão. Apesar das limitações de estudos na área, os resultados indicam que o conteúdo Lutas é reconhecido tanto na legislação educacional quanto por pesquisadores da área; os profissionais de educação física apresentam variadas dificuldades em aplicar as Lutas em suas aulas, alegando principalmente problemas em suas formações docentes; e os aspectos do Esporte Educacional aparecem de forma não contundente, sem aprofundamento empírico, nem pesquisas aplicadas a esse tema específico. Conclui-se que o emprego das Lutas na escola é possível, mas requer enfrentamentos, e que a contextualização das Lutas dentro dos princípios do Esporte Educacional ainda é pouco explorada, tornando-se um campo de possibilidades para pesquisas futuras.

Palavras-chave: Esporte; Educação física; Escola; Lutas. 


\section{Resumen}

La Educación Física Escolar trabaja con un abanico de contenidos que tienen como objetivo contemplar la Cultura Corporal del Movimiento, entre estos se encuentran las Luchas. Utilizar la literatura para comprender cómo la investigación aborda este tema es esencial para comprender sus fortalezas y limitaciones. Siguiendo el método de revisión integrativa, el propósito de este estudio fue identificar los posibles aportes de las Luchas en la formación humana integral de los estudiantes, en el contexto del Deporte Educativo. Una búsqueda preliminar de literatura identificó 192 artículos publicados entre 2015 y 2020. Los estudios fueron evaluados dentro de tres categorías: Luchas en el ámbito escolar, formación docente y aspectos del Deporte Educativo. La revisión resultó en 6 artículos que cumplieron con los criterios de inclusión y exclusión. A pesar de las limitaciones de los estudios en el área, los resultados indican que el contenido de Lutas es reconocido tanto en la legislación educativa como por los investigadores del área; Los profesionales de la educación física tienen diversas dificultades para aplicar las luchas en sus clases, principalmente alegando problemas en su formación docente; y los aspectos Educativos Deportivos aparecen de forma poco convincente, sin profundizar empíricamente, ni investigaciones aplicadas a esta temática específica. Se concluye que el uso de las peleas en la escuela es posible, pero requiere enfrentamientos, y que la contextualización de las peleas dentro de los principios del Deporte Educativo aún está poco explorada, por lo que es un campo de posibilidades para futuras investigaciones.

Palabras clave: Deporte; Educación física; Escuela; Luchas.

\section{Introduction}

Studies in education area open a range of immeasurable research possibilities, which can permeate the fields of teaching, social, teacher training, public policies for education, culture, etc. However, these concerns drive this desire for knowledge.

To identify these gaps, approaches, and possibilities motivated the conduction of this investigation, in which we sought to analyze scientific production of the area to understand the role of Struggles at school, as a component of School Physical Education, not just as part of the curriculum and content of the classes, but also its possible implications in social field of students' lives. According to Moura et al. (2019, translated by author) "searching literature is one of ways to know the production of a specific area, either to identify gaps or to find possibilities that inspire other ways of looking at a given phenomenon".

The objective of this research is to identify possible contributions of Struggles into integral human formation of students, in Educational Sport context. Following to Tubino (2010, translated by author) "the issue of the Right to sport can be concluded by stating that the forms of exercising this Right are: 1) Sport-Education; 2) Sport-Leisure; 3) Performance Sport”. Educational Sport, in line with Tubino (2006, translated by author), "should be referenced by principles of inclusion, participation, cooperation, co-education and co-responsibility". The integrative review method was adopted, aiming to meet the study problem: what does Brazilian academic production deal with about the teaching of Struggles content within School Physical Education context?

About integral human formation, as stated by Tonet (2006, translated by author) "when, however, this formation is stripped of its superficial and ideological elements, it shows that it is nothing more than manpower formation for capital. The author says that "the right of everyone to comprehensive training is proclaimed".

In line to Tonet (2014), it is necessary five requirements to develop an emancipatory education: "They are: 1) knowledge about the end to be achieved (human emancipation); 2) appropriation of knowledge about historical process and, specifically, about capitalist society; 3) knowledge of specific nature of education; 4) minimum of specific contents to be taught; 5) articulation of educational activities with struggles, both specific and general, of all workers".

Both National Curriculum Parameters (Brasil, 1998, translated by author) and the Common National Curriculum Base (Brasil, 2018, translated by author) explain Physical Education has Struggles as part of its integrality, which must be worked on to understand and exercise the Movement Corporal Culture.

According to Rosário and Darido (2005, translated by author) "in the Western school model, Physical Education is the 
curricular component that more directly addresses the human being in movement and its relationship with society, through its different contents".

Although they are part of the most remote expressions of human beings, Struggles must be present in any Physical Education curriculum proposal, as they are part of the cultural heritage of humanity. However, it is necessary to reframe Struggles, so that they can contribute to educational objectives proposed for School Physical Education (Carreiro, 2005, translated by author).

As part of human culture, struggles represent an effective means of education and a highly important set of contents for school Physical Education, because, whatever the struggle type, it requires respect for rules, hierarchy and discipline, valuing preservation of physical and mental health of its practitioners. Struggles, as well as other contents of physical education, must be approached at school in a reflective way, directed to broader purposes than just developing physical capabilities and potential (Souza \& Santos, 2010, translated by author).

In accordance with Rufino and Darido (2013, translated by author) "actually, Struggles content, according to some authors in the area, is still little explored by most teachers of School Physical Education". The contradictions between Brazilian educational legislation and researchers about Struggles have given us concern, when we realize that, even though guaranteed by law, Struggles do not seem to be protagonists in educational process. Investigating what scientific production reports about Struggles at school, through literary production, is this research motivation.

This study has scientific and social relevance. It is an integrative review format research, which provides synthesis, organization, and systematization of knowledge for application in results. It is social because it is concerned with investigating how Struggles are inserted in educational process and their possible implications for integral human formation of young students.

\section{Methodology}

Integrative review was chosen for conduction around this study. According to Mendes et al. (2008, translated by author), "this research method allows for synthesis of multiple published studies and for general conclusions regarding a particular area of study. Integrative literature review consists over construction of a literature broad analysis, contributing to discussions on research methods and results, as well as reflections on future studies".

To get closer to what Brazilian academic production deals with Struggles, an integrative review was used, which following to Souza et al. (2010, translated by author), it is a methodology that provides synthesis of knowledge and result applicability of significant studies to practice.

Integrative review is the broadest methodological approach regarding reviews, allowing inclusion of experimental and non-experimental studies for a complete phenomenon analyzed understanding. It also combines data from theoretical and empirical literature, in addition to incorporating a wide range of purposes: concept definitions, theory reviews and evidence, and methodological analysis problems for a particular topic (Souza et al., 2010).

Following databases were consulted: LILACS, PubMed, Scopus, Web of Science and Scielo. Titles, abstracts, and studies were analyzed in full for selection of articles, seeking those addressed the content Struggles into school environment. Twelve articles were selected and resulted in three categories (Moura et al., 2019): Struggles into school environment, Teacher Training, and Educational Sports Aspects. It was found that current research points to a greater concern about Teacher Education and Methodological and Didactic Aspects. Characters that send Educational Sports are mentioned, however without a scathing scientific deepening, generating possibilities and needs for further research in this area.

Select articles came from described databases above, that were published between 2015 and 2020, available online, written in English or Portuguese. Initial screening step used previously defined inclusion and exclusion criteria (Table 1) to 
select titles and abstracts from 192 found articles.

Table 1 - Inclusion and exclusion criteria to select titles and abstracts.

\begin{tabular}{l}
\hline Inclusion criteria \\
\hline Original Articles \\
Articles published between 2015 and 2020 \\
Present any search descriptors in title, keywords and/or abstract \\
Studies published in Portuguese or English \\
Exclusion criteria \\
Event summaries, book chapters \\
Systematic Reviews, Theses and Dissertations \\
Unrelated articles, duplicates, unavailable full texts, articles with abstracts only \\
\hline
\end{tabular}

Source: Authors.

Sampaio and Mancini's (2007, translated by author) criteria were followed to carry out the research. Authors say that "systematic review must go through five phases for its realization: 1) defining question; 2) seeking scientific evidence; 3) reviewing and selecting content; 4) analyzing methodological quality of studies; 5) presenting results".

\section{Results and Discussion}

The first step, a starting question was adopted: What does academic production discourse about Struggles teaching into school environment? The second step, databases to be used were delimited. The databases choosing criteria were recurrence in research with similarities around this study. Thus, databases used were LILACS, PubMed, Scopus, Web of Science and Scielo. Search was carried out between December 2020 and January 2021.

Three electronic searches were carried out in databases presented, and, for each research, search descriptors were adopted to contemplate as many articles as possible about studied topic. Table 2 shows the completed research and the descriptors listed.

Table 2 - Search descriptors used in electronic search of databases.

\begin{tabular}{ll}
\hline & Search descriptions \\
\hline 1st Search & jiu-jítsu OR jiu jitsu AND educação \\
2nd Search & lutas AND escola AND ensino \\
3rd Search & "artes marciais" AND educação AND ensino \\
\hline
\end{tabular}

Source: Authors.

The 1st Research was carried out with the search descriptors jiu-jitsu OR jiu jitsu AND educação, and returned these following number of articles, as shown in Table 3: 
Table 3 - 1st Search: Search descriptions: jiu-jítsu OR jiu jitsu AND educação.

\begin{tabular}{l|l|l}
\hline \multicolumn{2}{c|}{} & Return \\
\hline \multirow{4}{*}{ Databases } & LILACS & 9 \\
\cline { 2 - 3 } & PubMed & 2 \\
\cline { 2 - 3 } & Scielo & 1 \\
\cline { 2 - 3 } & Scopus & 0 \\
\cline { 2 - 3 } & Web of Science & 115 \\
\cline { 2 - 3 } & & Total: 127 \\
\hline
\end{tabular}

Source: Authors.

Data from the 2nd Research are shown in Table 4, which search descriptors lutas AND escola AND ensino were adopted:

Table 4 - 2nd Search: Search descriptions: lutas AND escola AND Ensino.

\begin{tabular}{l|ll}
\hline \multicolumn{2}{c}{} & Return \\
\hline \multirow{4}{*}{ Databases } & LILACS & 20 \\
\cline { 2 - 3 } & PubMed & 0 \\
\cline { 2 - 3 } & Scielo & 16 \\
\cline { 2 - 3 } & Scopus & 0 \\
\hline & Web of Science & 0 \\
\hline
\end{tabular}

Source: Authors.

To the 3rd Research search descriptors "artes marciais" AND educação AND ensino were adopted, whose data are shown in Table 5:

Table 5 - 3rd Search: Search descriptions: “artes marciais” AND educação AND Ensino.

\begin{tabular}{l|ll}
\hline \multirow{2}{*}{} & & Return \\
\cline { 2 - 3 } Databases & LILACS & 25 \\
\cline { 2 - 3 } & PubMed & 0 \\
\cline { 2 - 3 } & Scielo & 4 \\
\cline { 2 - 3 } & Scopus & 0 \\
\hline & Web of Science & 0 \\
\hline
\end{tabular}

Source: Authors.

Multiple searches of electronic databases, carried out on January 12, 2021, generated a total of 192 references, including duplicates. Complete search generated 54 articles in LILACS, 2 in PubMed, 21 in Scielo, zero in Scopus and 115 in Web of Science. After initial screening of titles and abstracts that addressed content "Struggles into school environment", 12 articles were obtained (Figure 1).

Following initial phase, the second step was implemented with articles complete reading. The objective of this step was to find "gaps, whether to find possibilities", to contemplate the three categories: Struggles into school environment; Teacher Training and Aspects of Educational Sport (Moura et al., 2019).

After 12 articles complete reading, it was necessary to discard 6 of them: 5 articles were discarded because they were 
not addressing the problem proposed by this study, and 1 article was discarded because it was a book review (Figure 1). Although discarded articles present search descriptors used in electronic searches of databases, their contents did not meet the investigative expectations of this analysis. In the third step, with the full reading, information contained in articles was interpreted. It was observed that most of analyzed texts brought relevant information about three categories proposed in this analysis: Struggles into school environment; teacher training and aspects of Educational Sport. We then proceeded with global dialogic interpretation of 6 resulting articles (Table 6), seeking, thus, their thematic approaches, possibilities, and gaps.

Figure 1 - Flowchart: reducing process for found articles on the databases.

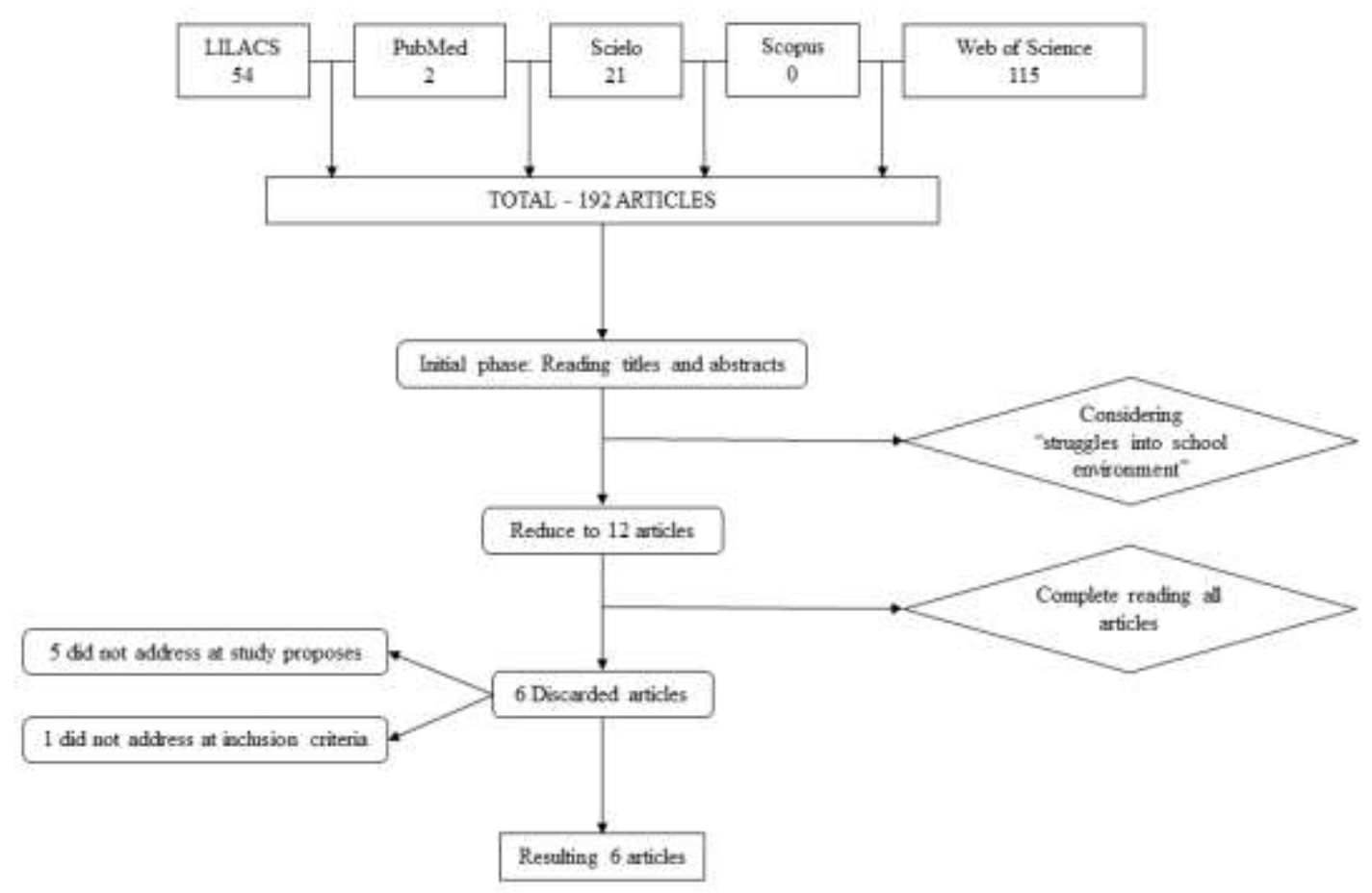

Source: Authors.

Table 6 - Resulting articles.

1) The Teaching of Fights in Physical Education Classes: Analyze of Pedagogical Practice in the Light of Experts - Rufino, L. G. B., \& Darido, S. C. (2015).

2) The Perception of School Directors in the City of Jaguariúna about Combat Sports - Rodrigues, A. I. C., Baião, A. A. Jr., Antunes, M. M., \& Almeida, J. J. G. (2017).

3) Martial arts on physical education classes: a proposal to pedagogic practice - Alencar, Y. O., Silva, L. H., Lavoura, T. N., \& Drigo, A. J. (2015).

4) Production of Knowledge about Wrestling in the School Curriculum of Physical Education - Santos, M. A. R., \& Brandão, P. P. S. (2019).

5) Fights of education: an experience report in public school - Lacerda, R. P., Silva, J. P., Lovise, A., \& Mourão, L. N. (2015).

6) Educação Física Escolar e Artes Marciais: entre o combate e o debate - Correia, W. R. (2015). 


\section{Struggles into school environment}

In line with Rufino and Darido (2015, translated by author), "Struggles teaching is ensured in terms of curricular guidelines, but it tends to be a content little discussed by many higher education courses in Physical Education, which results in problems for its effectiveness in school environment".

Infrastructure lack in schools and material absence to work with physical struggling practices appear as harmful causes for teaching of this content in Physical Education classes, which may even be true. However, this obstacle is not exclusive to Struggles content, but a reality to work on any theme in elementary school, in any content of curriculum, because, among many structural deficiencies, textbooks, laboratories, adequate classrooms, among others are lacking problems that are part of Brazilian public-school reality. Sport ends up being the main content of classes and this has a very strong historical root in Physical Education, which dates to the 1970s (Santos \& Brandão, 2019, translated by author).

Santos and Brandão (2019) and Alencar et al. (2015, translated by author) state that "Struggles must be conceptually established, as well as resignified for a more effective action as Movement Corporal Culture content". According to Santos and Brandão (2019), "solidification of Struggles as specific knowledge requires not only the determination of specific characteristics, but also conceptual agreement by scientific community". In line with Alencar et al. (2015) "thus, it is necessary to reframe the struggles/martial arts so that they can effectively contribute to Movement Corporal Culture construction of school-age children".

It is gotten that struggles/martial arts, as one dimension of Movement Corporal Culture content historically constructed by humanity, presenting itself as a manifestation of the most different cultures, civilizations, and societies, should be part of a set of knowledge produced into school environment by Physical Education. Therefore, it appears that several contents are possible to be worked on during school training, to contribute to a greater experience of Movement Corporal Culture (Alencar et al. 2015).

Regarding legal parameters and pedagogical practice of Struggles, Lacerda et al. (2015, translated by author) state that "PCNs guide pedagogical practice, but they do not determine which struggling modality is the best or most suitable for Physical Education classes".

This curricular parameter does not differentiate between martial arts and Struggles, treating everything as "Struggles", following the reasoning that every martial art is considered a struggle, but not every struggle is considered a martial art and this definition was used in present work. Thus, it is important to remember Struggles are not only systematized techniques, but also a set of cultural values built and reconstructed over time, which must be thought of as instruments of learning and school socialization (Lacerda et al. 2015).

About analyzed articles, another point addressed, a concern by authors such as Rodrigues et al. (2017) and Alencar et al. (2015) was about relation to image of violence associated to practice of struggling/martial arts. According to Rodrigues $e t$ al. (2017) "we believe democratization of combat sports can happen, reducing fear and its association with violence and aggressiveness".

This is another debatable argument, violent behavior is a feature present in society, and regardless of the content addressed into school environment, the way of conducting is fundamentally important - theoretical-methodological foundation and didactic approach -pedagogical - of thematization (Alencar et al., 2015).

\section{Teacher Formation}

Authors (Santos \& Brandão, 2019; Alencar et al., 2015; Rodrigues et al., 2017; Rufino \& Darido, 2015; Lacerda et al., 2015; Correia, 2015, translated by author) present their thoughts on Teacher Training in School Physical Education area. 
Correia (2015) analyzes speeches of Physical Education teachers interviewed: "I didn't have fight classes" or "classes were very bad or limited". Author argues that manifestations point to a restriction factor about encouragement of teachers in the process of appropriating S/AM/CSM ${ }^{1}$ as school content. Arguments such as "I've never fought" and "I'm not a fighter" are recurrent as a denial of these activities regarding teaching profession.

Insecurity to teach Struggles at school originates quite emphatically as lack of mastery this content, resulting in an insufficient approach to Struggles at school or even in superficiality of their pedagogical treatment. Restrictive factors presented by participants are not limited to teaching and learning process of Struggles, nor are they reduced only to contents to be taught, denoting implications about understanding of teaching work itself (Rufino \& Darido, 2015).

The issue of professional training can be a restrictive factor in teacher's pedagogical practice and, consequently, a restrictive factor to use of Struggles/martial arts as content in Physical Education classes. We can infer those problems encountered in knowledge systematization and pedagogical treatment of Struggles in training itself reflect a weakened training as a whole, starting with the way in which contents that talk with this knowledge are conducted at university, being offered electively or in a fragmented way (Santos \& Brandão, 2019).

According to Rodrigues et al. (2017) "we can understand in Physical Education courses, students learn mainly didactic-pedagogical parts of combat sports teaching, with the purpose of introducing these activities into Physical Education classes at school exclusively by teachers trained in this course".

It is necessary to bring to light opinions and representations of teachers who are directly involved in teacher education, since until now the field of Physical Education in Brazil has invested little in understanding Struggles training in higher education, as well as in its relationship with pedagogical practice found in field of School Physical Education (Rufino \& Darido, 2015).

Teacher's role is extremely important in combat sports knowledge transmission, regarding its insertion in school environment. Improvement of didactics in its teaching is also essential when we consider importance in formation of individuals at school. We understand pedagogical practices should be prioritized with an emphasis on professional training, to propose projects for combat sports, whether at school or outside this context (Rodrigues et al. 2017).

In line with Rufino and Darido (2015) "this implies to Physical Education teacher, especially those who do not have much knowledge about Struggles bodily manifestations, numerous dilemmas can contribute to lack of approach to these practices, or even, with ways very superficial to teach these contents".

It is necessary to overcome historical ties regarding gaps how Struggles have been treated in training, a fact that suggests importance of new studies, especially with larger samples and coming from other regions, as well as indicating the need for transformations that can, in fact, to value these practices as manifestations of Movement Corporal Culture that must be properly taught at school, throughout Physical Education classes (Rufino \& Darido, 2015).

According to Lacerda et al. (2015) "even though many teachers do not have instruction and training for struggling, do not have experience in daily life or at undergraduate, it is necessary to look for other ways to work this aspect of Movement Corporal Culture”.

Alencar et al. (2015) presents some alternatives to Struggles use, for example: "use of an audiovisual resource can make up lack of contact with skill by teacher and provide necessary information so that students are able to experience skills. There are many pedagogical tools available (videos, magazines, photos, websites, etc.) for teachers to obtain information about the topic".

${ }^{1}$ S/AM/CSM: Struggles, Martial Arts and Combat Sports Modalities 
According to Rodrigues et al. (2017), "a possible practice comes through external partnerships, such as professionals qualified in martial arts who can collaborate with this action of School Physical Education, within the school". As maintained by authors "association with other professionals should also be part of this integration within school community, proposing attitudes such as creation of new work routines".

Teaching materials are one of elements that make up school curriculum. It is necessary to consider education is a social action that requires constant reflections, as well as studies and analyzes do not cease to seek qualitative leaps in teaching and learning processes of all curricular components, such as Physical Education. In Struggles case, diversification of materials, if well used, can help about development of pedagogical proposals that contribute to their inclusion in a critical and creative way (Rufino \& Darido, 2015).

As stated by Alencar et al. (2015) "it is necessary to reflect and modify teachers' attitude and their pedagogical practices, to offer diversity of practice in their classes and promote Movement Corporal Culture in all its possibilities". It is evident that, more than alternatives to Struggles teaching, teaching attitude must be modified.

Rufino and Darido (2015), highlight Initial and Continuing Education Courses as alternatives to improving teacher training. In line with authors, this action must be able to support future professionals with a wide spectrum of knowledge, methodologies, didactic possibilities, and knowledge from the most diverse origins that allow them to understand their area of training. In addition, they must be able to value continuous search about development of their practice, a fact to which proposals for continuing education can significantly contribute.

Recognition of continuing education is a way to provide new reflections, as well as new meanings about practice. However, it should not be based only on technical-instrumental formats that establish a hierarchical order of relationship between those responsible for training and teachers involved in pedagogical practice (Rufino \& Darido, 2015).

Continuing education is a fundamental aspect to contribute to teachers in what corresponds to teaching and learning process of Struggles at school, in addition to allowing them to reflect on their own actions, reframe them and understand the social, historical, and cultural conditions that these bodily manifestations present. However, it is worth noting that it is necessary to carefully analyze how this process has been developed, which requires initiatives that can contribute to Physical Education teachers, especially those who do not have many relationships with these bodily practices (Rufino \& Darido, 2015).

About Correia's (2015) perspective, however, "admitting the possibility of multiple information spaces that can be mobilized throughout continuing/permanent training, we can relativize immobilizing and fatalistic dimension of this complaint". Author adds that, "given that a teaching career can reach a vitality around 25 to 30 years, the issue of undergraduate (three or four years) cannot be taken as a univocal or restricting factor". According to author, "if School Physical Education has merit and challenge of having as its object of teaching and learning this great "web" of cultural manifestations as a reference, its protagonists must inevitably understand that appropriation of knowledge from movement culture is task about entire teaching career".

Analyzing the speech - "I don't like, and I'm not interested in working with Struggles" - by an interviewed professor, Correia (2015) states that, in view of this announcement, we can impertinently challenge this notion as we do "what we like" and "what matters" are not coherently circumscribed over domains of teaching autonomy. Teaching responsibility calls on each teacher and teacher to reassess their relationship with object of teaching and learning. Immediate and unjustified refusal by some professors to get involved with certain curricular demands can be understood as inconsequential spontaneity.

\section{Educational Sport Aspects}

It was noticed in authors' statements (Alencar et al., 2015; Rodrigues et al., 2017; Rufino \& Darido, 2015; Lacerda et 
al., 2015; Correia, 2015, translated by author) that they traced pertinent considerations about social perspectives of Struggles, as part of School Physical Education.

Combat sports should be offered as a possibility, allowing children and young people new experiences around rescue of behavioral, social, and cultural values, benefiting their development and training. Social relations arising from combat classes, as in other sports, are seen as very important and should be more emphasized as pointed out by school leaders. Working with self-esteem and respect greatly favors social relationships of students with their friends, family, and other members society (Rodrigues et al., 2017).

On a global scale, we can admit martial arts have achieved such a projection, whose dimensions give it a status that transcends restricted concept of physical practice and physical activity. Currently, they can be understood as a relevant political and economic phenomenon, with wide and diverse penetration in the most diverse instances of social life. Presence of these activities is perfectly visible in academies spheres, institutes, associations, companies, media, in the market of industry and sporting products commerce, in literary production and, contemporaneously, in public policies for sport, leisure, culture, health and education (Correia, 2015).

However, according to Rufino and Darido (2015), "compared to other more hegemonic body practices in media terms, Struggles do not have same notoriety". It can be seen, in this way, that Struggles as martial arts have their repercussion space increased, but that this sample still presents little significance when compared to more popular and consolidated sports modalities.

Another prominent factor is given to relationship between Struggles and violence. According to Rodrigues et al. (2017) "violence is strongly emphasized in discourse of school leaders. They believe combat sports would be great important, allowing the release of energy, helping students' self-control, balancing emotional, psychological, mental and physical aspects".

We believe more than releasing energy and containing violence and anxiety, other factors are equal and even more important in this category. Combat sports teach us how to deal with defeat and fight for victory, respecting our own limits and those of colleagues we fight against. It is important to emphasize this concern with society, here represented by school leaders, because by democratizing the practice of combat sports it will be possible to improve information provided and present benefits that these practices can bring to student lives (Rodrigues et al., 2017).

Usually, when the theme is combat sports, it is common to think first about philosophy, values passed on and behaviors to be taught. There is no doubt about benefits that these practices can also bring as physical activity, as we are complete and not fragmented beings, in which, to achieve our well-being, we must be healthy and happy in every way. Thus, as quality of life is a subjective value that encompasses different aspects of human life, these combat sports functions enable different forms of acquisition and exercise of this value by their practitioners (Rodrigues et al., 2017).

As claimed by Alencar et al. (2015) "Struggles/martial arts, for being part of curricular proposal and for being a content historically constructed by society, needs to be socialized to students". According to Correia (2015) "it is the social function of school education, articulated with specificity of Physical Education, which should condition didactic and pedagogical transformation of teaching and learning objects".

Thinking more closely about technical elaborations such as percussion blows, keys, twists, strangulations, and projections, for example, require a better contextualization about perspective of School Physical Education objectives and the "Escola Cidadã". Their economic, social, political and, especially, socio-behavioral impacts justify the interest and interfaces of these cultural objectifications as elements and contents to be transformed/assimilated by purposes and purposes of scientific and educational institutions (Correia, 2015). 
Due to great social importance and potential for formation of human being in all its fullness, Struggles/martial arts theme deserves to be investigated by researchers in Physical Education, to contribute so that it effectively becomes part of Brazilian Physical Education content classes (Alencar et al., 2015).

\section{Conclusion}

After the analysis, it was observed that Struggles into school environment are possible, through School Physical Education, however its realization requires confrontations. School Physical Education, when approaching the Struggles component, has a richly varied range of possibilities to be worked on, however there is no pre-determined orientation, ready in this regard. It can be understood that Struggling component is present through School Physical Education, as an integral part of this discipline curriculum.

Analysis proposed by this study allowed us to verify an interweaving of information that ranges from restrictive factors about teaching action, justifications supported by weaknesses in training, actional alternatives in face of difficulties, proposals for improvement in training and ethical-professional considerations. Some problems stand out that hinder actions of Physical Education with content Struggles, from deficient infrastructure to lapses in teacher training. Importance over conceptual concatenation was also highlighted, and that it is up to scientific approach to equalize this issue. In addition, a process of reframing the Struggles must be considered, mainly aiming at their affirmation as an integral part of Physical Education curriculum, in an effective character, as well as Movement Corporal Culture.

While cited authors present restrictions to teaching actions, there are also statements that go back to possible causes, or justifications, for these difficulties to occur, and deficient teacher education is listed with more emphasis within the research. As highlighted, one of the most emphasized obstacles by authors was respecting Teacher Education, however, its implementation requires confrontations. Analyzed literature pointed out that gaps left by insufficient training, when considering Struggles content, affects these professional actions directly. It was observed Struggles are discredited contents within Physical Education, when other more popular and hegemonic sports activities are taken as a parameter. Under the justification of "non-training" or "incomplete training" that would not provide conditions for teachers to develop this content with due security.

Even in view of problematic situation presented, both restricting actions of teachers and problems in their training, authors claim these are not final causes, which would result in a total non-use of Struggles into school environment. Authors emphasize that it is possible to employ different actions that make Struggles feasible into school environment. Not undermining encountered and faced barriers but demonstrating possibilities for this field. Among actions in favor of better practices of Struggles into school environment, use of Initial and Continuing Education Courses stood out, referring to their importance for qualification and maintenance of teacher education. Thus, enabling contact with different methodologies and experiences may add knowledge to Physical Education professionals, as well as stimulating search for solutions to area concerns.

Another emphasis was given to Educational Sport aspects. Within their works, Struggles were presented as historically consolidated social manifestations, part of society's reality since its inception. Analyzed literature presents, even superficially, social significance of Struggles at school. However, consistent arguments about this topic were not identified, especially when it comes to assertions that deal with the impacts of Educational Sport generated by Struggles, at school-age young people lives, especially when questioning its implications in citizenship formation of this public.

It was perceived use of Struggles into school environment is not only possible but relevant, even considering adversities involved. As in other areas, initial teacher education must be continually seen, thought, and rethought, and 
continued education is necessary to increase good practices and scientific and social growth.

It was noted studies in Struggling field have been focused their directions on epistemological and methodological bases of Physical Education praxis into school environment. However, regarding implications of Educational Sport, it is a deficiency explored field, thus opening possibilities for scientific investigations.

For future researches, it would be beneficial to investigate impacts and hypothetical benefits that Educational Sport could have on young students lives. Future researchers can increase the sample worked in this study, insert more variables and quantify the data. This study is preliminary and allows for expansion of its proposed research fields.

\section{References}

Alencar, Y. O., Silva, L. H., Lavoura, T. N., \& Drigo, A. J. (2015). As lutas no ambiente escolar: uma proposta de prática pedagógica. R. Bras. Ci. e Mov./ Brazilian Journal of Science and Movement. Brasília, DF. 23 (3): 53-63. http://dx.doi.org/10.18511/rbcm.v23i3.5092

Brasil. (2018). Ministério da Educação. Base Nacional Comum Curricular. Brasília, DF. http://basenacionalcomum.mec.gov.br/

Brasil. (1998). Ministério da Educação. Parâmetros Curriculares Nacionais. Ensino Médio. Ministério da Educação. Secretaria de Educação Média e Tecnológica. Brasília, DF. Ministério da Educação. http://portal.mec.gov.br/setec/arquivos/pdf/BasesLegais.pdf

Carreiro, E. A. (2005). Lutas. in: Darido, S. C., \& Rangel, I. C. A. (org.). Educação física na escola: implicações para a prática pedagógica. Rio de Janeiro, RJ: Guanabara Koogan. p. 244-261.

Correia, W. R. (2015). Educação física escolar e artes marciais: entre o combate e o debate. Revbraseducfísesporte. São Paulo, SP. 29(2):337-344. http://dx.doi.org/10.1590/1807-55092015000200337

Lacerda, R. P., Silva, J. P., Lovise, A., \& Mourão, L. N. (2015). Ensino de lutas: relatos de uma experiência na rede pública. Salusvita. Bauru, SP. v. 34, n. 3, p. 437-453. https://secure.unisagrado.edu.br/static/biblioteca/salusvita/salusvita_v34_n3_2015_art_04.pdf

Mendes, K. D. S., Silveira, R. C. D. C. P., \& Galvão, C. M. (2008). Revisão integrativa: método de pesquisa para a incorporação de evidências na saúde e na enfermagem. Texto \& Contexto-Enfermagem, 17(4), 758-764.

Moura, D. L., Silva, I. A. L. Jr., Araújo, J. G. E., Sousa, C. B., \& Parente, M. L. D. (2019). O ensino de lutas na educação física escolar: uma revisão sistemática da literatura. Pensar a prática, Goiânia, GO. v. 22: 51677. https://doi.org/10.5216/rpp.v22.51677

Rodrigues, A. I. C., Baião, A. A. Jr., Antunes, M. M., \& Almeida, J. J. G. (2017). The perception of school directors in the city of Jaguariúna about combat sports. J. Phys. Educ. Campinas, SP. v. 28, e2809. https://doi.org/10.4025/jphyseduc.v28i1.2809

Rosário, L. F. R., \& Darido, S. C. (2005). A sistematização dos conteúdos da educação física na escola: a perspectiva dos professores experientes. Revista Motriz, Rio Claro, SP. v.11, n.3, p.167-178, set./dez. https://www.rc.unesp.br/ib/efisica/motriz/11n3/10LRF.pdf

Rufino, L. G. B., \& Darido, S. C. (2015). O ensino das lutas nas aulas de educação física: análise da prática pedagógica à luz de especialistas (The teaching of fights in physical education classes: analyze of pedagogical practice in the light of experts). Rev. Educ. Fís/UEM. Maringá, PR. v. 26, n. 4, p. 505-518, 4. trim. https://doi.org/10.4025/reveducfis.v26i4.26441

Rufino, L. G. B., \& Darido, S. C. (2013). Possíveis diálogos entre a educação física escolar e o conteúdo das lutas na perspectiva da cultura corporal. Conexões. Campinas, SP. v. 11, n. 1, p. 144-170. https://doi.org/10.20396/conex.v11i1.8637635

Sampaio, R. F., \& Mancini, M. C. (2007). Estudos de revisão sistemática: um guia para síntese criteriosa da evidência científica. v. 11, n. 1. São Carlos-SP: Revista Brasileira de Fisioterapia. São Carlos, SP. p. 83-89, 2007. https://doi.org/10.1590/S1413-35552007000100013

Santos, M. A. R., \& Brandão, P. P. S. (2019). Produção do conhecimento em lutas no currículo da educação física escolar. Movimento. Porto Alegre, RS. v. 25, e25024. https://doi.org/10.22456/1982-8918.78143

Souza, M. T., Silva. M. D., Carvalho, R. (2010). Integrative review: What is it? How to do it? Einstein. São Paulo, SP. 8(1 pt 1):102-6. https://doi.org/10.1590/S1679-45082010RW1134

Souza, T. P. Jr., \& Santos, S. L. C. (2010). Jogos de oposição: nova metodologia de ensino dos esportes de combate. EFDeportes.com, Revista Digital. Buenos Aires, Argentina. v. 14, n. 141, fevereiro. http://www.efdeportes.com/efd141/metodologia-de ensino-dos-esportes-de-combate.htm

Tonet, I. (2006). Educação e formação humana. Revista Ideação. Campus de Foz do Iguaçu, PR. v. 8 n 9 p. 9-21 $2^{\circ}$ semestre. https://doi.org/10.48075/ri.v8i9.852

Tonet, I. (2014). Atividades educativas emancipadoras. Práxis Educativa, Ponta Grossa, PR. v. 9, n. 1, p. 9-23, jan./jun. DOI:10.5212/PraxEduc.v.9i1.0001

Tubino, M. J. G. (2010). Estudos brasileiros sobre o esporte: ênfase no esporte-educação. Editora da Universidade Estadual de Maringá, Eduem. Maringá, PR. http://hdl.handle.net/10183/40871

Tubino, M. J. G., Garrido, F., Tubino, F. (2006). Dicionário enciclopédico Tubino do esporte. Serviço Nacional de Aprendizagem Comercial Editora. Rio de Janeiro, RJ. 